\title{
Penerapan Non-Corporal Punishment di Madrasah Aliyah: Studi Kasus di MAN 1 Sungai Penuh dan MAN Kemantan Kerinci
}

\author{
Deri Wanto, \\ Program Doktor UIN Raden Fatah Palembang \\ deriwanto56@gmail.com
}

Abdullah Idi

UIN Raden Fatah Pelembang

\author{
Ahmad Jamin \\ Pascasarjana IAIN Kerinci, Jambi
}

\begin{abstract}
This article aims to examine and analyze non-corporal punishment in the character development of Madrasah Aliyah students in Jambi province. This research applied case study approach with purposive sampling technique. The data were collected by observing, interviewing, and documentating. The result showed that the application of non-corporal punishment works well in Madrasah Aliyah of Jambi province, student character can also be formed from noncorporal punishment contribution. The indicators could be seen by; (1) there is a change in the process of learning when the teacher implements non-corporal punishment, and the non-corporal punishment implementation in extracurricular activities goes well, (2) student character such as discipline can be developed with noncorporal punishment more obedient to madrasah regulations, and discipline enforcement by non-corporal punishment raises awareness and motivation of students who can improve their academic performance, (3) while the supporting factor of non-corporal punishment implementation in Madrasah Aliyah is cooperation of all elements of madrasah (headmasters, classteachers, teachers, janitor, security, and parents), while those that hinder the application of noncorporal punishment is a team that should always be supervised, full teacher activities, the teachers who do not care about the discipline, the distance of student residence to school, and financing.
\end{abstract}

Keywords: Application, Non-Corporal Punishment, Madrasah Aliyah

Abstrak: Tulisan ini bertujuan untuk menelaah non-corporal punishment dalam pengembangan karakter siswa Madrasah Aliyah di provinsi Jambi. Penelitian ini menggunakan pendekatan studi kasus dengan teknik purposive sampling. Data dikumpulkan dengan teknik observasi, wawancara, dan studi dokumentasi. Penelitian ini menemukan bahwa penerapan non-corporal punishment berjalan dengan baik di madrasah 
60 | BELAJEA : Jurnal Pendidikan Islam, Vol. 3, No. 1, 2018

aliyah provinsi Jambi, karakter siswa juga dapat dibentuk dari kontribusi non-corporal punishment tersebut. Indikatornya tampak pada: (1) terdapat perubahan dalam proses pembelajaan ketika guru menerapkan non-corporal punishment, serta penerapan non-corporal punishment dalam kegiatan ekstrakurikuler berjalan dengan baik, (2) karakter siswa seperti disiplin dapat dikembangkan dengan non-corporal punishment yang menjadikan siswa lebih taat kepada peraturan madrasah, dan penegakan disiplin dengan cara non-corporal punishment menimbulkan kesadaran dan motivasi siswa yang dapat meningkatkan performance akademiknya, (3) adapun faktor pendukung penerapan noncorporal punishment di madrasah aliyah adalah kerjasama seluruh elemen madrasah (kepala madrasah, wali kelas, guru, petugas kebersihan, keamanan, dan orang tua siswa), sedangkan yang menghambat penerapan non-corporal punishment ialah tim kerja yang harus selalu diawasi, aktifitas guru yang padat, masih adanya guru yang tidak peduli dengan kedisiplinan, jarak tempat tinggal siswa dengan madrasah, dan pembiayaan.

Kata Kunci: Penerapan, Non-Corporal Punishment, Madrasah Aliyah

\section{Pendahuluan}

Memasuki era globalisasi saat ini dengan ditandai oleh kemajuan ilmu dan teknologi yang semakin hari begitu pesat perkembangannya sehingga menuntut perubahan mendasar dalam berbagai bidang, baik politik, perekonomian, budaya dan termasuk pendidikan. Tantangan dunia pendidikan seperti ini perlu diberijawaban oleh lembaga pendidikan, terutama lembaga pendidikan Islam dimana norma-norma agama senantiasa dijadikan sumber pegangan. ${ }^{1}$

Pendidikan menjadi pilar yang sangat strategis dalam proses internalisasi dan sosialisasi nilai-nilai, karena pendidikan bersentuhan langsung dengan aspek manusia. Di dalamnya terkandung kekuatan-kekuatan yang harusdistimulasi, sehingga potensi-potensi dimiliki berkembang secara optimal,terutama dalam menghadapi berbagai bentuk tantangan di masa depan. Delors mengemukakan bahwa dalam menghadapi tantangan masa depan, kemanusiaan melihat pendidikan sebagai sesuatu yang berharga yang sangat 
dibutuhkandalam usahanya meraih cita-cita perdamaian, kemerdekaan dan keadilan sosial. ${ }^{2}$

Pendidikan dalam Islam adalah pendidikan berdasarkan pada normanorma dan nilai-nilai Islam, pendidikan bertujuan untuk menumbuh kembangkan pola kepribadian manusia yang bulat, melalui latihan kejiwaan, otak, perasaan dan indra. Pertumbuhan aspek spritual, intelektual, imajinasi, jasmani, ilmiah dan bahasa sehingga dapat mendorong tercapainya kesempurnaan hidup dan tujuan akhir, yaitu merealisasikan sikap penyerahan diri sepenuhnya kepada Allah SWT. ${ }^{3}$

Secara umum,pendidikan harus mampu menghasilkan manusia sebagai individu dan anggota masyarakat yangsehat dan cerdas dengan; (1) kepribadian kuat dan religius dalam menjunjung tinggi budaya luhur,(2) kesadaran demokrasi dalam kehidupanberbangsa dan bernegara,(3) kesadaran moral hukum dalam pelaksanaan sebuah aturan, dan (4) kehidupanmakmursejahtera dalam kehidupan individu di masyarakat.

Guna menghasilkan para siswa seperti di atas tentu tidaklah mudah, karena dalam setiap sekolah memiliki kondisi masalah atau pelanggaran (delinquency) siswa yang berbeda pula. Hal ini merupakan produk dari konstitusi defektif dari mental dan emosi;yaitu mental dan emosi siswa yang belum matang, yang labil dan jadirusak/defektif, sebagai akibat dari proses pengkondisian oleh lingkungan yangburuk. ${ }^{4}$

Terkadang dari delinkuen siswa tersebut bisa menciptakan berbagai konflik yang terjadi di sekolah. Mulai dari kurangnya minat belajar siswa dengan sifat malas, tidak peduli dengan pelajaran sehingga siswa sering tidak mengerjakan tugas, dan masalah attention getting behaviours yang biasanya ditunjukkan oleh siswa dengan sering datang terlambat ke sekolah atau masuk kelas.

Hal terbaru ketika berbicara tentang punishment dalam dunia pendidikan ialah pada kamis 1 Februari 2018 di Sampang Madura seorang siswa SMAN 1 Torjun Kabupaten Sampang Provinsi Jawa Timur berinisial HI kini diamankan

${ }^{2}$ Delors, Education: The Necessary Utopia, Pengantar di dalam 'Treasure Within' Report the International Commission on Education for the Twenty-firs Century", (Paris: UNESCO Publising, 1996), hal. 13

${ }^{3}$ Djauhari, Pendidikean Islam dari Masa ke Masa, (tt: Mairifah, 1997), hal. 60, Vol. 3

${ }^{4}$ Kartono, Patologi Sosial; Tiga Gangguan-gangguan Kejiwaan, (Jakarta: Raja Grafindo Persada, 1997), hal. 58 
polisi setelah menganiaya gurunya yang bernama Ahmad Budi Cahyono hingga meninggal dunia. ${ }^{5}$ Peristiwa ini berawal dari dalam kelas saat gurumenyampaikan materi pelajaran di kelas XII. Guru menegur siswa karena tidak menghiraukan pelajaran yang disampaikan oleh guru. Sampai beberapa kali ditegur, siswa tetap tidak menghiraukan sehingga terjadi debat antara keduanya. Setelah perdebatan terjadi, siswa kemudian menganiaya guru tersebut.

Melihat hal tersebut, tentu perlu adanya sebuah kebijakan atau aturan yang dibuat oleh kepala madrasah dan guru untuk mengikat siswa sehingga berpengaruh langsung terhadap pengembangan karakter siswa di madrasahyaitu iklimmadrasah, etos belajar, dan prestasi belajar siswa.

Ternyata Islam telah dulu membuktikan tentang bagaimana penerapan punishment yang akan diberikan kepada seseorang, sesuai dengan firman Allah surat an-Nisa ayat 34. "Wanita yang kamu khawatirkan nusyusnya, maka nasehatilah mereka dan pisahkanlah dari tempat tidur mereka dan pukullah mereka, kemudian jika mereka mentaatimu maka janganlah kamu mencari-cari jalan untuk menyusahkan mereka"?

Rasulullah SAW menerapkan punishment kepada para sahabat. Dalam penjelasan Nabi Muhammad SAW bahwa punishment (hukuman) yang diterapkan Islam hanyalah untuk mendidik, menerapkan syariat Islam, menjalankan perintah Allah dan meninggalkan larangan-Nya. Sesuai dengan hadis Nabi:

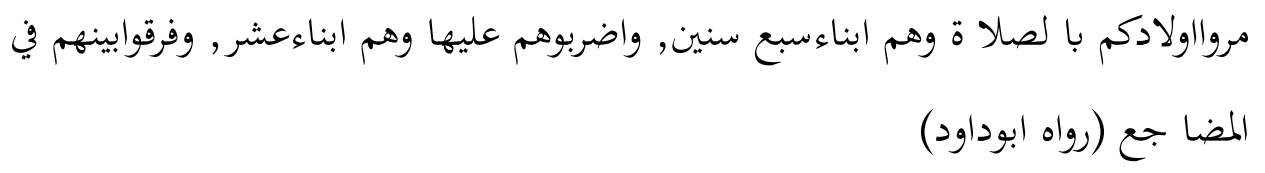

"Perintabkanlah anak-anakmu mengerjakan shalat ketika usia mereka tujuh tabun, dan pukullah mereka jilka meninggalkannya saat mereka berusia sepulub tabun, dan pisabkanlah tempat tidur mereka." (H.R. Abu Dawud).

${ }^{5}$ Kompas, Edisi Jumat 2 Pebruari 2018

${ }^{6}$ Lihat al-Quran dan terjemahan surat an-Nisa ayat 34

${ }^{7}$ Ayat ini memang menjelaskan tentang nusyus, yakni seorang suami diperkenankan memberikan hukuman kepada istrinya yang serong dengan laki-laki lain. Namun korelasi yang dapat diambil dari ayat ini dalam penerapan non-corporal punishment ialah terdapat tahapan dalam memberikan hukuman. Tahap pertama, dengan memberikan nasehat melalui cara dan waktu yang tepat. Tahap kedua, dengan bentuk mengabaikan atau tidak mempedulikannya. Tahap ketiga, dengan fisik, yakni pukulan itu tidak terlalukeras serta tidak terlalu menyakitkan. 
Berdasarkan hadis tersebut, meskipun hukuman dengan menggunakan pukulan, akan tetapi harus memperhatikan prinsip pendidikan yang bertujuan agar anak jera dan beralih kepada tindakan mulia. ${ }^{8}$

Observasi awal penulis pada Madrasah Aliyah (baca; MA) di MAN 1 Sungai Penuh dan MAN Kemantan Kerinci Jambi menunjukkan gambaran mengenai penerapan punishment bagi siswa yang melanggar aturan sekolah, baik berupa sanksi non fisik dalam bentuk pembayaran denda, maupun sanksi lainnya. Hal ini dilakukan dalam rangka pengembangan karakter siswa terlebih yang terkait dengan kedisiplinan dan aturan sekolah.

Pada MAN 1 Sungai Penuh dan MAN Kemantan Kerinci Jambi, pihak madrasah sangat menghindari hukuman fisik kepada siswa, sebab tindakan sanksi fisik (punishment) yang bersifat fisik, dianggap tidak lagi relevan bagi proses pendidikan dewasa ini. Oleh sebab itu, maka madrasah kini menerapkan hukuman dalam bentuk non-corporal bagi siswa yang bermasalah atau melanggar. Biasanya penerapan non-corporal punishment kepada siswa berbentuk denda dengan cara harus menyerahkan buku satu buah jika tidak hadir tanpa keterangan dan bolos, atau membawa pupuk kandang satu kantong jika tidak mengerjakan PR (pekerjaan rumah) dan latihan.

Meskipun ditekankan pada denda, pada observasi awal juga terlihat, bahwa punishment (hukuman) dibagi dalam dua bentuk, yakni corporal dan noncorporal punishment, hukuman non-corporal punishment diberlakukan guna memudahkan guru dalam pembentukan karakter siswa dan juga dianggap lebih baik dan aman. Namun demikian, penentuan jumlah dan nominal denda dilakukan berdasarkan kesepakatan antara guru dan murid yang bermasalah tersebut.

Kebijakan-kebijakanyang diterapkan oleh Madrasah dalam hal pemberian punishment berupa denda di atas, menurut hemat peneliti hendaknya diperhatikan juga efektifitas dan efesiensinya, dan juga harus memiliki konsensus bersama antara pihak pimpinan madrasah, tenaga kependidikan dan juga pendidik itu sendiri.

Kerjasama yang baik antara kepala madrasah dengan memberikan wewenang kepada guru dalam penerapan non-corporal punishmentmerupakan salah satu bukti bahwa karaktersiswa akan terbentuk ketika mereka diikat oleh sebuah aturan. 
Hal lain yang harus diperhatikan dalam pengembangan karakter siswa di MAN 1 Sungai Penuh dan MAN Kemantan Kerinci Jambi adalah menumbuhkan kepercayaan diri siswa, menumbuhkan kondisi lingkungan belajar yang nyaman di madrasah, dan memberikanrewardtentunya kepada mereka yang berprestasi, disiplin, dan berbakat.

Berdasarkan latar belakang masalah di atas, makadapat dirumuskan permasalahan penelitian sebagai berikut:

a. Bagaimanapenerapannon-corporal punishment terhadap siswa Madrasah Aliyah.

b. Bagaimana kontribusi penerapan non-corporal punishment terhadap pengembangan karakter siswa Madrasah Aliyah.

c. Apa saja faktor pendukung dan penghambat penerapan non-corporal punishment di Madrasah Aliyah.

Metode yang digunakan ialah metode kualitatif, yang mana penelitian kualitatif merupakan penelitian yang menggunakan latar alamiah, dengan maksud menafsirkan fenomena yang terjadi dan dilakukan dengan jalan melibatkan berbagai metode yang ada. Metode yang sering digunakan adalah wawancara, pengamatan, dan pemanfaatan dokumen. ${ }^{9}$

Penelitian ini menggunakan pendekatan studi kasus karena melalui pendekatan ini diharapkan segala bentuk kejadian yang tampak di lapangan dapat diinterpretasikan makna dan isinya lebih dalam.

\section{Punishment: Corporal dan Non-Corporal}

"Punishment (hukuman) adalah salah satu bentuk reinforcement (penguatan) negatif yang menjadi alat motivasi jika hal tersebut diberikan secara tepat dan bijak sesuai dengan prinsip-prinsip pemberian hukuman". ${ }^{10}$ Selanjutnya "Hukuman (punishment) merupakan prosedur yang dilakukan untuk memperbaiki tingkah laku yang tak diinginkan dalam waktu singkat dan dilakukan dengan bijaksana". ${ }^{11}$ Mengutip pendapat Skinner dalam

hal. 2

${ }^{9}$ Lexy J Moleong, Metodologi Penelitian Kualitatif, (Bandung: Remaja Rosdakarya, 2007), 2017), hal. 221

${ }^{10}$ Sardiman, Interaksi dan Motivasi Belajar, (Jakarta: Rajawali Pers, 2011), hal. 94

${ }^{11} \mathrm{Abu}$ Ahmadi dan Widodo Supriyono, Psikologi Belajar, Jakarta: Rineka Cipta, 
Abimanyu mengemukakan bahwa "hukuman (punishment) adalah konsekuensi yang menghasilkan berkurangnya tingkah laku". ${ }^{12}$

Hukuman adalah salah satu bentuk sanksi yang harus diterima oleh seseorang yang merupakan akibat dari sebuah pelanggaran atas peraturan yang ditetapkan. Hukumanakan diberikan sebagai alat pendidikan dimana hukuman yang diberikan harus dapat mendidik dan menyadarkan peserta didik. ${ }^{13}$

Sejalan dengan makna hukuman (punishment) di atas, Ormrod menjelaskan bahwa "hukuman (punishment) merupakan konsekuensi yang menurunkan frekuensi respons yang mengikutinya". ${ }^{14}$ Artinya dengan pemberian punishment maka tindakan-tindakan negatif yang timbul dalam suatu kondisi akan berkurang. Selanjutnya, Slavia dalam Abimanyu berpendapat bahwa "hukuman (punishment) adalah konsekuensi yang tidak memberi penguatan tetapi melemahkan tingkah laku". ${ }^{15}$ "Hukuman (punishment) merupakan konsekuensi yang tidak memperkuat (dalam arti memperlemah) perilaku". ${ }^{16}$

Sejalan dengan pengertian hukuman (punishment) yang telah disebutkan, Sadulloh mengemukakan pendapat Langeveld bahwa:

Menghukum adalah suatu perbuatan yang dengan sadar, sengaja menyebabkan penderitaan bagi seseorang biasanya yang lebih lemah, dan dipercayakan kepada pendidik untuk dibimbing dan dilindungi, dan hukuman tersebut diberikan dengan maksud anak benar-benar merasakan penderitaan tersebut. $^{17}$

"Punishment(hukuman) biasanya diberikan kepada anak ketika apa yang diinginkan oleh pendidik tidak tercapai, atau ada perilaku anak yang tidak sesuai dengan norma-norma yang diyakini oleh sekolah tersebut". ${ }^{18}$ Berdasarkan pengertian-pengertian mengenai punishment(hukuman) yang telah dipaparkan,

\footnotetext{
${ }^{12}$ S. Abimanyu dkk, Strategi Pembelajaran 3 SKS, Jakarta: Direktorat Jenderal Pendidikan Tinggi Departemen Pendidikan Nasional, 2008), hal. 1

${ }^{13}$ Ali Imron, Manajemen Peserta Didik. (Jakarta: Bumi Aksara, 2012), hal. 169

${ }^{14}$ J.E. Ormrod, PsikologiPendidikan: Membantu Siswa Tumbuh dan Berkembang, (Jakarta: PenerbitErlangga, 2009), hal. 454

15S. Abimanyu, dkk, Strategi Pembelajaran 3..., hal. 11 2011), hal. 121

${ }^{16} \mathrm{~A}$. Rifa'i, dan T.A. Catharina, PsikologiPendidikan, (Semarang: UNNES Press,

${ }^{17}$ Usman Sadulloh, Pedagogik (IlmuMendidik), (Bandung: Alfabeta, 2011), hal. 124

${ }^{18}$ A. Shoimin, A, 68 Model Pembelejaran Inovatif dalam Kurikulum 2013, (Yogyakarta: Ar-Ruzz Media, 2014), hal. 157-158
} 
dapat ditarik kesimpulan bahwa punishment(hukuman) dalam bidang pendidikan adalah salah satu bentuk alat motivasi yang dapat digunakan oleh pendidik untuk memperbaiki tingkah laku peserta didik yang tidak sesuai dengan normanorma yang diyakini dengan jalan melemahkan perilaku, dilaksanakan sesuai dengan prinsip-prinsip pemberian punishment(hukuman) secara tepat dan bijaksana.

Di sisi lain punishment dipahami sebagai suatu gambaran daritindakan menghukum terhadap suatu kesalahan ${ }^{19}$, yang dikategorikan ke dalam tiga batasan oleh HanafiAnshari. Pertama perubahan rasasakit atau tidak suka terhadap subjek karena kegagalan perbuatan untukmenyesuaikan diri terhadap batasan dalam eksperimen, kedua suaturangsangan dengan valensi negatif atau rangsangan yang sanggup untukmengubah rasa sakit atau ketidak senangan, dan ketiga gangguan terhadapperiode pengurangan pada orang yang resmi bersalah, lawannya reward. ${ }^{20}$

Dari beberapa pendapat di atas, dapat ditarik sebuah kesepakatan bahwa punishment adalah suatu tindakan yang kurang menyenangkan dan dilakukan secara sadar serta sengaja dikarena suatu pelanggaran terhadap sebuah aturan. Dengan pemberian punishmentmaka seseorang yang melanggar akan sadar akan segala pelanggaran yang dilakukannya dan tidak akan mengulangi tindakannya tersebut.

\section{Tujuan Punishment}

Pemberian punishment adalah cara terakhir yang dilakukan, ketika semua sarana dan metode mengalami kegagalan dan tidak mencapai tujuan yang diinginkan. Punishment harus dilakukan pada saat yang tepat dan sesuai dengan kadar pelanggaran yang diperbuat.

Thorndike dalam Danim dan Khairil mengemukakan efek yang akan muncul jika diberikan reward dan punishment bahwa "belajar menjadi diperkuat jika disertai dengan perasaan menyenangkan atau memuaskan. Sebaliknya, hal ini akan melemah ketika dikaitkan dengan pengalaman yang tidak menyenangkan". ${ }^{21}$ Ditinjau dari pernyataan tersebut, efek psikologis dari pemberian reward dan punishment memiliki efek yang berbeda. Efek yang ditimbulkan oleh reward berupa perasaan yang berkaitan dengan kepuasan,

${ }^{19} \mathrm{~W}$. Noah, Dictionary of English Language, (New York: Portland, 1989), hal. 1165

${ }^{20}$ M.H. Anshari,Kamus Psikologi, (Surabaya: Usaha Nasional, 1996), hal. 582

${ }^{21}$ S. Danim dan Khairil, Psikologi Pendidikan (dalam Perspektif Baru), (Bandung: Alfabeta, 2011), hal. 126 
kesenangan, dan kebanggaan. Sedangkan efek yang ditimbulkan oleh punishment berupa perasaan yang berkaitan dengan ketidaksenangan, kekecewaan, dan ketidakpuasan.

Efek-efek semacam ini yang nantinya akan dipilih oleh siswa untuk menentukan tindakan mana yang akan dia lakukan. Apakah dia akan melakukan tindakan yang menimbulkan rewardatau yang dapat menimbulkan punishment.

Punishmentmerupakan salah satu metode penerapan konsekuensi peserta didik jika tindakannya tidak sesuai dengan tujuan yang dicapai. Punishment terpaksa diberikan, namun dalam penerapannya harus mempertimbangkan syarat-syarat sebagai berikut:

a. Dasar dari pelaksanaann punishmentialah kasih sayang dan rasa tanggung jawab, bukan karena alasan dendam atau pembalasan. Karena itu, janganlah menghukum siswa pada saat pendidik sedang marah (terganggu emosinya).

b. Tujuan yang diinginkan dalam penerapan punishment adalah untuk melakukan perbaikan tingkah laku atau sifat-sifat yang tidak baik, terutama dalam kepentingan siswa dimasa yang akan datang.

c. Punishment yang bersifat edukatif akan menimbulkan rasa menyesal oleh siswa, dan tidak akan menimbulkan dampak sakit hati atau dendam pada siswa. Penyesalan atas diri sendiri dibarengi dengan kesadaran siswa bahwa punishment juga dapat menimbulkan rasa kurang enak pada pendidik akibat perbuatannya, merupakan pertanda bahwa punishment tersebut diterima secara wajar oleh siswa.

d. Punishmentseharusnya disudahi dengan pemberian maaf oleh guru kepada siswa. Setelah siswa menunjukkan penyesalannya maka hubungan edukatif antara guru dan siswa harus dipulihkan, dengan berbagai sikap dan kata-kata pendidik yang menunjukkan bahwa dia telah menerima kembali siswa ini seperti sediakala.

\section{Bentuk Punishment}

Secara umum punishment bisa berbentuk corporal dan non-corporal. Adapun bentuk lain yang merupakanpenjabaran dari kedua jenis punishment ini sangatlah beragam. Hal inimenuntut daya kreativitas masig-masing guru dalam rangka mewujudkan bentukpunishment yang efektif dalam rangka mendisiplinkan perilaku anak. 
Bentuk-bentuk punishment yang biasa diterapkan oleh guru dalam proses pembelajaran dapat terbagi menjadi beberapa bentuk diantaranya:

a. Pemberian stimulus derita, misalnya bentakan, cemoohan, atau ancaman.

b. Pembatalan perlakuan positif, misalnya mengambil kembali suatu mainan atau mencegah anak untuk bermain-main bersama temantemannya.

Penerapan punishmentmemang diperbolehkan dalam pendidikan, akan tetapi harus melihat batas kewajaran dan dengan orientasi tujuan untuk mendidik. Punishment dilakukan apabila ditemui siswa yang tingkah lakunya melampaui batas-batas tertentu.

Abimanyu menyebutkan beberapa bentuk punishment yang nantinya dapat dilakukan dalam proses pembelajaran, antara lain: hukuman presentasi, hukuman penghapusan, dan time out. ${ }^{22}$

Pada penerapan bukuman presentasi dilakukan penggunaan konsekuensi yang tidak menyenangkan atau rangsangan yang tidak disenangi, seperti siswa disuruh menulis "saya tidak akan mengganggu kelas" 100 kali atau cacian dan tamparan, serta bisa juga dalam bentuk bentakan. Hukuman penghapusan dapat dilakukan dalam bentuk menghapus penguatan, contohnya yaitu siswa dihukum dengan tidak boleh istirahat, berdiri di depan kelas, atau dihilangkan hakhaknya. Selanjutnya time outdapat dilakukan dengan cara menghukum siswa yang tingkah lakunya melanggar tata tertib kelas dengan menyuruh berdiri di sudut kelas, dengan tujuan agar tingkah laku nakal itu dapat hilang atau agar siswa lain terhindar dari tingkah lakunya yang nakal. Beberapa bentuk hukuman tersebut memang cukup efektif dalam meluruskan perilaku siswa yang menyimpang. Akan tetapi dalam pelaksanaannya, guru hendaknya memperhatikan batasanbatasan dalam pemberian punishment termasuk batas kewajaran serta diterapkan jika siswa benar-benar sudah melampaui batas kewajaran dalam bertindak.

Perlu diketahui bahwa bagi guru yang akan menerapkan punishment harus mempunyai kesepahaman bersama tentang anak-anak, dimana anak-anak adalah pribadi yang unik, keunikan ini mengharuskan para guru untuk bersikap lebih toleran dengan segala pola dan tingkah mereka, baik yang lucu menggemaskan sampai dengan yang menjengkelkan.

22S. Abimanyu, dkk, Strategi Pembelajaran 3..., hal. 1-11 
Bentuk-bentuk punishment yang akan diberikan kepada siswa sesuai dengan kesalahan atau pelanggaran yang diperbuat. Bagi siswa yang suka ribut dapat dipisahkan tempat duduknya di pojok kelas atau disuruh keluar kelas, siswa yang tidak mengerjakan tugas dapat diberikan tugas berlipat dan pengurangan nilai, siswa yang terlambat mengumpulkan tugas digunakan denda dan siswa yang sering kali melanggar peraturan, maka tidak dapat diampuni kesalahannya maka diberikan hukuman diskors. ${ }^{23}$

Dalam proses pembelajaran ada beberapa bentuk punishment yang dapatditerapkanmenurutSuharsimiArikuntojenis-jenishukumanantara lain:

a. Pengurangan Skor atau Penurunan Peringkat

Pada jenis hukuman seperti ini yang paling banyak dipraktekan di sekolah terutama diterapkan ketika siswa terlambat datang, tidak atau terlambat mengumpulkan tugas.

b. Pengurangan Hak

Hukuman jenis ini yang paling efektif dikarenakan sesuai dengan selera siswa. Dalam hukuman ini memang harus ada pengawasan yang ketat dari guru sehingga dapat memilih pengurangan yang tepat bagi setiap siswa.

c. Hukum Berupa Denda

Dalam hukuman ini bukan hukuman yang berupa uang namun hukuman ini lebih banyak memberikan makna "pembayaran" (Payment). Namun ada juga sekolah yang memang menerapkan pembayaran denda berupa uang.

d. Pemberian Celaan

Hukuman semacam ini menggabungkan dengan hukuman yang lainya, siswa yang melanggar peraturan diperuntukan bagi siswa akan mendapat celaan. Guru menuliskan kesalahan siswa dalam buku catatan khusus atau keanehan (anecdotal record).

e. Penahanan Sesudah Sekolah

Hukuman ini diberikan ketika jam sekolah selesai siswa disuruh tinggal di sekolah dengan batas waktu yang ditentukan oleh guru.Yang perlu diperhatikan dalam penerapan hukuman semacam ini ialah bagaiman peranan guru yang dapat menemani siswa sambil memberikan masukan dan teguran pada saat hukuman dilaksanakan.

M. Ngalim Purwanto membedakan hukuman menjadi dua macam yaitu: ${ }^{24}$

${ }^{23}$ Suharsimi Arikunto, Manajemen Pengajaran Secara..., hal. 176

${ }^{24}$ M. Ngalim Purwanto, Ilmu Pendidikan Teoritis dan Praktik. (Bandung: Remaja Rosdakarya, 2007), hal. 189 
a. Hukuman preventif, yaitu hukuman yang dilakukan dengan maksud agar tidak atau jangan terjadi pelanggaran. Hukuman ini bermaksud untuk mencegah jangan sampai terjadi pelanggaran, sehingga hukuman ini dilakukan sebelum pelanggaran itu dilakukan.

b. Hukuman represif, yaitu hukuman yang dilakukan karena adanya pelanggaran. Hukuman ini dilakukan setelah terjadi pelanggaran atau kesalahan.

William Stern dalam M. Ngalim Purwanto membedakan tiga macam hukuman yang disesuaikan dengan tingkat perkembangan anak yang akan menerima hukuman, antara lain: ${ }^{25}$

a. Hukuman Asosiatif

Kebiasaan orang-orang mengasosiasikan antara hukuman dan pelanggaran, antara penderitaan yang diakibatkan oleh hukuman dengan perbuatan pelanggaran yang dilakukan.

b. Hukuman Logis

Hukuman logis diberikan kepada anak yang sudah cukup dewasa. Dengan ini anak akan mengerti bahwa hukuman itu adalah akibat yang logis dari pekerjaan atau perbuatannya yang tidak baik. Anak akan menyadarii bahwa dia mendapat hukuman dikarenakan akibat dari kesalahan yang diperbuatnya.

c. Hukuman Normatif

Hukuman ini adalah hukuman yang diperuntukan untuk memperbaiki moral anak. Hukuman ini diberikan terhadap pelanggaran mengenai norma dan etika. Hukuman normatif erat kaitannya dengan pembentukan watak dan kepribadian anak.

\section{Abu Ahmadi dan Nur Uhbiyati menjelaskan macam-macam hukuman yaitu: ${ }^{26}$}

a. Hukuman Membalas Dendam

Guru yang merasa tidak senang karena siswa berbuat salah akan dihukum. Tetapi guru justru merasa senang/puaskarena berhasil menyakiti siswa. Hukuman ini memuaskan guru tetapi untuk kepentingan siswa sama sekali tidak ada. Hukuman semacam ini tidak boleh diterapkan karena dampaknya tidak baik. 
b. Hukuman Badan/Jasmani

Hukuman ini memberikan akibat yang merugikan bagi siswa, karena dapat menimbulkan gangguan kesehatan bagi siswa. Misalnya guru menangkap siswa yang kedapatan sedang merokok, maka siswa diberikan hukuman untuk merokok terus menerus selama waktu sekolah. Hal ini dapat menyebabkan siswa batuk atau pusing.

c. Hukuman Jeruk Manis

Menurut tokoh yang mengemukakan teori hukuman ini, Jan Ligthart, siswa yang nakal tidak perlu dihukum, tetapi didekati dan diambil hatinya. Misalnya di kelas ada siswa baru yang sombong tidak mau kenal dengan siswa lain, maka salah satu siswa berlaku baik, dengan demikian siswa yang sombong itu akan berubah menjadi baik dan membaur dengan siswa lain.

d. Hukuman Alam

Dikemukakan oleh J.J. Rousseau dari aliran naturalisme, berpendapat kalau ada anak nakal jangan dihukum, biarlah kapok/jera dengan sendirinya. Misalnya jika ada gadisyang sangat bebas dalam pergaulan tidak pernah ditegur maupun dimarahi orang tuanya, dibiarkan saja biar jera, akhirnya gadis itu merasa jera setelah berbadan dua.

Lain halnya dengan Maria J. Wantah yang mengemukakan bentukbentuk hukuman yaitu (a) Hukuman fisik, seperti menampar, memukul; (b) Hukuman dengan kata-kata, seperti mempermalukan, meremehkan, dan menggunakan kata-kata yang kasar; (c) Melarang, seperti tidak boleh menonton televisi sebelum mengerjakan tugas; (d) Hukuman dengan pinalti, seperti mengurangi uang saku anak apabila merusak sesuatu. ${ }^{27}$

Berdasarkan pendapat di atas, maka hukuman sebaiknya diberikan untuk mencegah jangan sampai terjadi pelanggaran, yaitu dengan menakutnakuti dan memberikan larangan terlebih dahulu kepada siswa atau membuat sanksi/ aturan jika pelanggaran terjadi. Kemudian hukuman juga dapat dilakukan dengan cara menerapkan apa yang menjadi kesepakatan awal dalam setiap pelanggaran yang terjadi.

\section{Fungsi Punishment}

Dalam Kamus Besar Bahasa Indonesia (KBBI) hukum adalah peraturan yang dibuat oleh suatu kekuasaan atau adat yang yang dianggap 
berlaku oleh danuntuk orang banyak. ${ }^{28}$ Artinya bahwa hukuman atau aturan yang dibuat agar dapat mengatur pergaulan hidup dalam hal ini pergaulan hidup siswa yang berada disekolah.

Menurut M. Ngalim Purwanto, hukuman adalah penderitaan yang diberikan atau ditimbulkan dengan sengaja oleh seseorang (orang tua, guru) sesudah terjadi suatu pelanggaran, kejahatan atau kesalahan. ${ }^{29}$

Hukuman dilakukan dalam bentuk pemberian penderitaan atau penghilangan stimulasioleh pendidik sesudah terjadi pelanggaran, kejahatan atau kesalahan yang dilakukan siswa. Hukuman bisa jadi sebagai penguat sifat negatif yang dilakukan oleh siswa, namun hukuman itu jika diberikan secara tepat dan bijak dapat menjadi alat motivasi.Karena padadasarnya sebuah hukuman yang dilaksanakan akan dapat menjadikan efek berupa perilaku, dalam hal ini apabila efek yang bersifat tidak menyenangkan bagi siswa maka efek ini disebut sebagai punishment.

Pemberian punsibmenttidak serta merta sebagai suatu tindakan balas dendam antara guru dan siswa yang tidak sesuai dengan harapan yang diinginkan, namun guru harus memahami segala bentuk prinsip-prinsip pemberian hukuman sebagai sanksi pendidikan. Dalam hal ini hukuman diartikan sebagai sesuatu yang dapat dijadikan sebuah pelajaran bagi siswa. Adapun fungsi penting dilaksanakan punishment bagi siswa antara lain:

a. Agar kesalahannya tidak terulang lagi

Anak pada dasarnya memiliki rutinitas yang tidak bisa dipisahkan dari kehidupan sehari-hari dengan adanya rutinitas yang dilakukan anak, maka kemudian akan menjadikan anak lalai. Faktor ini yang menyebabkan seorang anak menjadi lalai. ${ }^{30}$ (El-Ghany, 2009: 52). Andaikata anak melakukan kesalahan satu ataupun dua kali mungkin bisa dimaklumi, namun jika anak melakukan berulang kali, maka hukuman menjadi pilihan dan harus dilakukan agar anak jera (kapok) untuk melakukan kesalahanyang sama. ${ }^{31}$

b. Sebagai pelajaran dan hikmah

172

${ }^{28}$ D. Anwar, Kamus Lengkap Bahasa Indonesia, (Surabaya: KaryaAbditama, 2001), hal. hal. 186 2009), hal. 52

${ }^{29}$ M. Ngalim Purwanto, Psikologi Pendidikan,(Jakarta: PT Remaja Rosdakarya, 1995),

${ }^{30}$ A. El-Ghaniy, Saat Anak Harus Dibukum, (Yogyakarta: Power Books IHDINA, 31 A. El-Ghaniy, Saat Anak Harus..., hal. 53 
Anak akan belajar terhadap kejadian yang telah dia lalui. Kesalahan bagaimanapun juga akan menjadikan anak bisa mengambil tentang peristiwa yang akan dihadapinya dimasa yang akan datang. ${ }^{32}$ Dengan itu anak akan menjadi lebih berhati-hati dan sebagai pelajaran yang akan datang agar tidak mengulang peristiwa yang pernah dialaminya.

c. Konsistensi sebuah perjanjian

Pada dasarnya hukuman yang baik merupakan sebuah konsekuensi dari perjajian dari seorang guru terhadap siswa, jika siswa berbuat salah maka siswa akan mendapatkan hukuman.Baiknya lagi siswa yang melakukan kesalahan mau mengakui dan menyediakan diri untuk di hukum tanpa seorang guru yang mendesak untuk melakukan hukuman. ${ }^{33}$

Maria J. Wantah mengemukakan bahwa hukuman bertujuan untuk menghentikan siswa dalam melakukan sesuatu yang tidak sesuai dengan norma dan aturan yang berlaku dengan menggunakan metode yang memberikan efek jera baik secara biologis maupun psikologis. ${ }^{34}$

Maria J. Wantah menjelaskan fungsi hukuman adalah sebagai berikut: ${ }^{35}$

a. Hukuman dapat menghalangi pengulangan tindakan yang tidak diinginkan oleh masyarakat.

b. Hukuman dapat mendidik, sebelum anak mengerti peraturan, mereka dapat belajar bahwa tindakan tertentu benar dan yang lain salah dengan mendapat hukuman.

c. Hukuman sebagai motivasi digunakan untuk menghindari perilaku yang tidak diterima oleh masyarakat. Pengetahuan tentang akibat-akibat tindakan yang salah perlu sebagai motivasi untuk menghindari kesalahan tersebut.

Dalam pendidikan, hukuman dilakukan dengan tujuan yang berbedabeda. Hal ini sangat berkaitan erat dengan teori-teori tentang hukuman. M. Ngalim Purwanto menguraikannya sebagai berikut: ${ }^{36}$

a. Teori pembalasan

Dalam teori ini, hukuman dilakukan sebagai pembalasan dendam terhadap kelainan dan pelanggaran yang telah dilakukan seseorang. Teori ini tidak boleh digunakan di sekolah.

\footnotetext{
${ }^{32}$ A. El-Ghaniy, Saat Anak Harus..., hal. 54

${ }^{33}$ A. El-Ghaniy, Saat Anak Harus..., hal. 56

${ }^{34}$ Maria J. Wantah, Pengembangan Disiplin dan..., hal. 157

${ }^{35}$ Maria J. Wantah, Pengembangan Disiplin dan..., hal. 162

${ }^{36}$ M. Ngalim Purwanto, Ilmu Pendidikan Teoritik..., hal. 187
} 
b. Teori perbaikan

Pada teori ini, hukuman diberikan untuk memperbaiki anak agar tidak berbuat kesalahan lagi.

c. Teori perlindungan

Hukuman diadakan untuk melindungi masyarakat dari perbuatan-perbuatan yang tidak wajar. Dengan adanya hukuman ini, masyarakat dapat dilindungi dari kejahatan-kejahatan yang telah dilakukan oleh si pelanggar.

d. Teori ganti rugi

Teori ini diberikan hanya untuk mengganti kerugian-kerugian yang telah diderita akibat dari pelanggaran yang terjadi. Hukuman seperti ini banyak dilakukan dalam masyarakat atau pemerintah.

e. Teori menakut-nakuti

Hukuman diadakan untuk menimbulkan perasaan takut kepada si pelanggar akan akibatperbuatannya yang melanggar itu sehingga ia tidak akan melakukan perbuatan itu dan mau meninggalkannya.

Penelitian ini ingin melihat fungsi dari punishment yang mendidik. Di sini siswa diajarkan untuk berperilaku yang benar, sedangkan perilaku yang salah akan dikenakan hukuman. Hukuman diberikan untuk perbaikan agar siswa tidak mengulangi perilakunya yang salahsehinggasiswaakanberperilakudisiplin.

\section{PenerapanNon-Corporal Punishment terhadap Siswa Madrasah Aliyah}

Sudah menjadi sebuah tuntutan ketika dalam proses pembelajaran memang harus mengedepankan aspek disiplin dalam belajar. Disiplin belajar siswa adalah usaha untuk membina secara terus menerus kesadaran dalam belajar dengan baik dalam arti setiap orang menjalankan fungsinya secara aktif. ${ }^{37}$ Disiplin belajar siswa adalah suatu keadaan dimana orang-orang yang tergabung dalam suatu organisasi tunduk pada peraturan-peraturan yang telah ada dengan rasa senang hati." 38

Dari pengertian di atas dapat dipahami bahwa disiplin belajar siswa adalah usaha untuk membina kesadaran siswa secara terus menerus dalam belajar agar belajar dengan baik sesuai dengan fungsinya yang tergabung dalam suatu organisasi dan tunduk pada aturan-aturan yang telah ada.

Adapun kondisi siswa yang dikenakan hukuman dalam proses pembelajaran adalah ketika siswa datang terlambat, pulang cepat/ bolos padasaat jam pelajaran. Hukuman yang diberikan ketika siswa melanggar dengan

\footnotetext{
${ }^{37}$ Hadari Nawawi, Administrasi Pendidikan, (Jakarta: Gunung Agung, 1992), hal. 67 hal. 34

38 The Liang Gie, Kamus Administrasi, (Jakarta: BPA GAMA, Gunung Agung, 1992),
} 
memberikan tugas kepada siswa tersebut untuk membersihkan lingkungan madrasah. Akan tetapi, sebelum memberikan hukuman terlebih dahulu guru mempertimbangkan tingkat berat/ ringannya pelanggaran. Biasanya guru hanya memberikan arahan, bimbingan, peringatan dan pendekatan awal kepada siswa yang melanggartersebut.

Pada proses pembelajaran diharapkan terwujud beberapa hal diantaranya; Pertama, disiplin dalam proses pembelajaran di kelas. Yang mana suatu kondisi dikatakan tertib jika pendidik dan siswa mematuhi atau mentaati aturan kelas, sehingga mereka dapat melaksanakan tugas dan fungsi masingmasing secara efektif dalam pelaksanaan proses pembelajaran di kelas. Dengan demikian disiplin pembelajaran di kelas mencakup aspek-aspek suasana tertib, taat, tekun, dan ulet. Oleh sebab itu dalam belajar disiplin sangat diperlukan, karena disiplin dapat melahirkan semangat menghargai waktu, bukan menyianyiakan waktu dalam kehampaan. Bagi orang-orang yang berhasil dalam belajar dan berkarya disebabkan karena mereka selalu menempatkan disiplin di atas semua tindakan dan perbuatan.

Kedua, menumbuhkan kesadaran disiplin siswa dalam belajar. Disiplin siswa dalam belajar yang disebabkan kesadaran pentingnya ilmu pengetahuan membawa kondisi kelas dan siswa tersebut menjadi lebih dinamis dan produktif. Disiplin belajar seperti ini akan terwujud apabila kepemimpinan guru, wali kelas orang tua lebih partisipatif. Artinya guru, wali kelas dan orang tua, mau menerima siswa dengan segala kelebihan dan kekurangannya, memberikan kebebasan yang bertanggung jawab, waktu yang cukup, memperhatikan potensi siswa, tidak memaksakan atau dipaksakan (bertindak lebih ikhlas). Bersamaan dengan itu guru memberikan penegertian dan pemahaman tentang kedudukan serta peran pendidikan dalam mempersiapkan diri untuk memasuki kehidupan di masyarakat.

Ketiga, disiplin siswa melalui bimbingan guru. Disiplin merupakan salah satu masalah yang perlu diperbaiki dengan bimbingan atau arahan. Bimbingan sebagai bantuan yang diberikan kepada siswa baik secara individu maupun secara kelompok agar mereka berkembang menjadi pribadi yang mandiri. ${ }^{39}$

Siswa yang mempunyai masalah perlu kiranya mendapatkan bimbingan, termasuk masalah disiplin dalam proses pembelajaran. Bimbingan terhadap siswa yang indisiplin dalam proses pembelajaran yang dimaksud adalah 
agar mereka dapat mengatasi diri untuk menghargai waktu kesempatan untuk belajar lebih efektif, mengingat siswa yang tidak menghargai waktu termasuk kategori orang yang merugi.

Keempat, disiplin siswa dalam proses pembelajaran karena adanya hubungan yang harmonis. Hubungan antara pendidik dengan siswa di sekolah idealnya dapat tercipta secara sehat dalam arti terwujud lues, supel, periang, tidak sombong dan tidak tinggi hati. Dikarenakan siswa memiliki sifat kepribadian yang unik dan berbeda-beda serta tahap pertumbuhan yang mempunyai ciri-ciri tertentu, dengan demikian akan terjadi perbedaan dalam berperilaku. Oleh sebab itu pendidik harus mampu untuk menciptakan hubungan yang kondusifdannyamandengansiswa.

Dengan melaksanakan ke-empat hal tersebut maka dalam proses pembelajaran akan berjalan lancar ketika guru menggunakan non-copporal punishmentyang menunjukkan bahwa terdapat perubahan dalam proses pembelajaran. Non-Corporal punishment merupakan salah satu bentuk penguatan yang negatif yang biasanya dilakukan ketika apa yang menjadi tujuan tertentu tidak tercapai, atau ada perilaku yang tidak sesuai dengan aturan-aturan yang berlaku. Penerapan non-corporal punishment hendaknya disesuaikan dengan kondisi siswa serta dengan memperhatikan pedoman penerapan punishment agar proses pembelajaran siswa dapat berkembang dengan maksimal.

\section{Kontribusi Penerapan Non-Corporal Punishment terhadap Pengembangan Karakter Siswa Madrasah Aliyah}

Karakter merupakan sebuah topik yang lagi hangat-hangatnya diperbincangkan dunia pendidikan pada saat sekarang ini. Namun sebenarnya Islam telah terlebih dahulu membahas masalah karakter dari dunia barat. Karakter memiliki banyak unsur, akan tetapi karakter yang akan dibahas dalam artikel ini ialah disiplin.

Orang yang mempunyai karakter adalah orang yang mempunyai disiplin tinggi karena mereka melakukan kebaikan dengan ketulusan, bukan karena disuruh atau diawasi orang lain. Disiplin diri sangat perlu dikembangkan karena disiplin muncul dari kesadaran, keyakinan, dan pemahaman, bukan disiplin yang muncul dari ketakutan. ${ }^{40}$

${ }^{40}$ Gede Raka, dkk, Pendidikan Karakter di Sekolab: Dari Gagasan keTindakan, (Jakarta: PT Gramedia, 2011), hal.113 
Jika berbicara tentang disiplin siswa tentu membahas tentang suatu keadaan tertib dan teratur yang dimiliki oleh peserta didik di sekolah, tanpa ada pelanggaran-pelanggaran yang merugikan baik secara langsung maupun tidak langsung terhadap siswa sendiri dan terhadap sekolah secara keseluruhan. ${ }^{41}$ Sedangkan disiplin kelas adalah keadaan tertib dimana guru dan siswa-siswa yang tergabung dalam suatu kelas tunduk kepada peraturan-peraturan yang telah ditetapkan dengan senang hati. ${ }^{42}$

Dampak dari pemberian hukuman non-corporal punishment terhadap karakter siswa diantaranya ialah:

Pertama, ketaatan dalam mematuhi aturan yang berlaku di sekolah. Kedisiplinan dapat mewujudkan keberhasilan siswa dalam meraih prestasi, dimana kedisiplinan ini membentuk sikap dan perilaku yang taat dan patuh terhadap norma-norma yang ada, baik di lingkungan keluarga, di sekolah, maupun di masyarakat.

Pemberian punishment yang bersifat non-corporal punishment di madrasah untuk membentuk sikap dan perilaku siswa agar patuh dan taat terhadap semua aturan atau norma hukum yang ada. Punishment atau hukuman yang diberikan oleh guru di madrasah adalah sebagai alat untuk mendidik dan membina para siswa, agar insyaf dan jera terhadap perlakuan atau perbuatan yang dilanggarnya. Dari wawancara peneliti didapatkan informasi tentang nilai-nilai karakter (disiplin) yang dapat diterapkan kepada siswa di madrasah adalah sebagai berikut.

Dua, ketertiban siswa dalam belajar di kelas. Ketertiban dalam belajar adalah kedisiplinan yang disadari oleh siswa untuk menerima pelajaran dengan baik, karena ketertiban merupakan salah satu bagian dari norma hukum yang berlaku, dimana tata tertib yang dibuat oleh sekolah adalah berbentuk peraturan-peraturan yang ada di sekolah, selain peraturan yang berasal dari lembaga resmi yang lainnya yang berwajib, seperti lembaga peradilan dan pemerintah merupakan keterikatan oleh suatu aturan hukum yang mengikat.

Ketertiban adalah suatu keadaan yang mencerminkan adanya keteraturan serta keseimbangan antara hak dan kewajiban dalam mentaati aturan-aturan yang ada sehingga tercipta keharmonisan dalam pergaulan antar

${ }^{41}$ Ali Imron, Manajemen Peserta Didik Berbasis Sekolah, (Jakarta: Bumi Aksara, 2012), Cet. Ke-2 hal. 172

42 Ali Imron, Manajemen Peserta Didik..., hal. 172 
warga sekolah termasuk di dalamnya adalah guru dan siswa, untuk menyadari hak dan kewajibannya masing-masing, karena setiap individu memiliki hak-hak tertentu, antara lain hak untuk hidup, hak untuk mengeluarkan pendapat, hak untuk memiliki tempat tinggal, dan hak untuk memiliki harta benda. Dalam hidup bermasyarakat, hak-hak pribadi tidak lagi bebas seluas-luasnya, tetapi perlu menyesuaikan diri dengan norma sosial atau norma hukum yang berlaku". ${ }^{33}$

Ketiga, siswa dituntut untuk taat terhadap aturan yang belaku di sekolah. Taat dan patuh adalah suatu sikap menerima serta melaksanakan suatu yang dibebankan kepada seseorang dengan rasa ikhlas dan penuh tanggung jawab tanpa ada paksaan dari siapa pun. Taat dan patuh terhadap peraturan yang berlaku berarti sikap menerima serta ikhlas melaksanakan peraturan yang berlaku dengan keteguhan hati tanpa paksaan dari siapa pun. ${ }^{44}$

Ketaatan merupakan keadaan sikap untuk menyadari aturan yang berlaku di lingkungan sekolah, agar tercipta suasana belajar yang kondusif, sehingga keharmonisan seluruh lingkungan sekolah akan tercermin, yaitu mentaati tata tertib yang berlaku tanpa paksaandarisiapapun, baik guru maupunsiswa.

Dengan adanya pembinaan kedisiplinan siswa melalui non-corporal punishment yang dilakukan di Madrasah Aliyah, siswa yang mulanya banyak melangar peraturan dan tata tertib madrasah menjadi lebih taat pada peraturan yang ada. Hal ini tidak terlepas dari pembinaan dan kesadaran siswa sendiri untuk hidup disiplin. Perilaku disiplin itu dapat terealisasikan apabila dalam pembinaan tersebut direncanakan dan dilakukan dengan baik.

\section{Faktor Pendukung dan Penghambat Penerapan Non-Corporal Punishment di Madrasah Aliyah}

Seorang guru atau pendidik harus memahami bahwa anak-anak adalah pribadi yang unik, keunikan ini mengharuskan para guru memiliki toleransi dengan segala pola dan tingkah laku mereka, baik yang lucu menggemaskan sampai dengan yang menjengkelkan.

\footnotetext{
${ }^{43}$ Depdiknas, Pedoman Penciptaan Suasana Sekolah yang Kondusif dalam Rangka Pembudayaan Budi Pekerti Lubur Bagi Warga Sekolah Buku II, Jakarta: Direktorat Jenderal Pendidikan Dasar dan Menengah, 2003), hal.10

${ }^{44}$ Soranji Dahlan dan Asy'ari, Pendidikan Kewarganegaraan untuk SMP Kelas VII, (Jakarta: Penerbit Erlangga, 2009)
} 
Agar punishment yang diberikan oleh pihak madrasah dapat berjalan sesuai dengan harapan hendaknya guru perlu memperhatikan beberapa langkah praktis dalam penerapan hukuman tersebut.

a. Adanya kerja sama kepala madrasah dengan wali kelas dan guru berupa selalu memberikan arahan kepada majlis guru agar selalu melaksanakan punishment terhadap siswa yang melakukan pelanggaran. Hal seperti ini sering diistilahkan oleh kepala Madrasah Aliyah Kemantan dengan istilah "nyinyir" yang berarti mengingatkan kembali dan terus menerus.

b. Adanya kerja sama guru dengan wali kelas dengan cara selalu melaporkan anak didik yang melakukan pelanggaran. Dalam kegiatan seperti ini guru telah memiliki kartu kontrol siswa yang disebut dengan "kartu tilang" yang berfungsi untuk mengawasi dan pelaporan terhadap siswa yang melakukan pelanggaran disiplin.

c. Adanya kerja sama petugas kebersihan dengan wali kelas atau guru dengan cara melaporkan ketika mendapatkan anak didik yang melakukan pelanggaran.

d. Adanya kerja sama petugas keamanan/ securiti dengan wali kelas atau guru dengan cara melaporkan ketika mendapatkan anak didik yang melakukan pelanggaran.

e. Dukungan dari orang tua siswa dalam bentuk nasehat melarang anaknya agar tidak melakukan perbuatan yang dilarang oleh sekolah karena memang orang tua telah diberi tahu dan menerima dengan sepenuh hati bahwa hukuman yang dilakukan pihak sekolah bertujuan baik dan tidak dengan cara kekerasan.

Adapun faktor penghambat pelaksanaan non-corporal punishment di madrasah aliyah provinsi Jambi di antaranya:

a. Tim kerja yang harus selalu diawasi oleh kepala madrasah

b. Guru dengan aktifitas yang sangat padat, sehingga ada beberapa siswa kurang mendapat perhatian dan terkontrol ketika melakukan kesalahan. Guru juga dituntut untuk bersabar dan juga memiliki waktu serta perhatian lebih terhadap siswa

c. Guru yang tidak mau peduli dengan penegakan kedisiplinan dan tata tertib madrasah

Selain ketiga faktor di atas, faktor penghambat penerapan non-corporal punishment di Madrasah Aliyah provinsi Jambi diantaranya jarak tempuh tempat tinggal siswa dengan madrasah, guru tidak mau memberikan izin kepada siswa 
yang sedang menjalani hukuman, karakter siswa yang beragam, dan terkait dengan dana/ pembiayaan kegiatan kedisiplinan.

\section{Kesimpulan}

Dari uraian dan data-data yang penulis sajikan dalam di atas, maka penulis akan memberi kesimpulan, yaitu:

1. Penerapan non-corporal punishment terhadap siswa madrasah aliyah di provinsi Jambi dalam proses pembelajaran berjalan dengan lancar. Hal ini dapat dilihat ketika guru menggunakan non-corporal punishmentyangberimbas terhadap perubahandalam proses pembelajaran.Non-Corporal punishment adalah wujud dari penguatan negatif yang dilakukan ketika tujuan yang ingin dicapai tidak terpenuhi, atau suatu perilaku yang tidaksesuai dengan tata tertib yang berlaku.Penerapan non-corporl punishment hendaknyadisesuaikan dengan kondisi siswa sertadengan memperhatikan pedoman penerapan punishment agar proses pembelajaran siswa dapat berjalan dengan maksimal.Kegiatan ekstrakurikuler merupakan kegiatan pendidikan di luarkurikulumsebagai penunjang kegiatan pendidikan formal yang berlangsung disekolah ketika diterapkan non-corporal punishment maka kegiatan ekstrakurikuler berjalan dengan baik.

2. Penerapan non-corporal punishment berkontribusi dalam pengembangan karakter (kedisiplinan) siswa madrasah aliyah provinsi Jambi. Dikarenakan pembinaan kedisiplinan siswa melalui non-corporal punishmentdapat menjadikan siswa lebih taat pada peraturan yang ada. Hal ini disebabkan pembinaan dan kesadaran siswa untuk hidup disiplin. Perilaku disiplin itu dapat terealisasikan apabila dalam pembinaan tersebut direncanakan dan dilakuakan dengan baik. Performance akademik atau prestasi siswa juga dipengaruhi oleh penerapan non-corporal punishment yang menuntut kepada siswa untuk hidup disiplin. Penegakan disiplin yang disertai dengan noncorporal punishment menimbulkan kesadaran kepada siswa sehingga siswa termotivasi untuk meningkatkan prestasinya.

3. Faktor pendukung penerapan non-corporal punishment diantaranya kerjasama kepala madrasah dengan wali kelas maupun guru, kerjasama wali kelas dengan guru yang melaporkan siswa yang didapati melanggar, kerjasama petugas kebersihan, kerjasama petugas keamanan, dan dukungan dari orang tua siswa. Selanjutnya faktor penghambat penerapan non-corporal punishment di madrasah aliyah provinsi Jambi adalah tim kerja yang harus selalu diawasi oleh kepala madrasah, aktifitas guru yang padat, ketidak pedulian guru, jarak tempuh tempat tinggal siswa dengan madrasah, guru tidak mau 
memberikan izin kepada siswa yang sedang menjalani hukuman, karakter siswa yang beragam, dan terkait dengan dana/ pembiayaan kegiatan kedisiplinan.

\section{Bibliografi}

Abimanyu S, dkk, 2008, Strategi Pembelajaran 3 SKS, Jakarta: Direktorat Jenderal Pendidikan Tinggi Departemen Pendidikan Nasional.

Ali Imron, 2012, Manajemen Peserta Didik. Jakarta: Bumi Aksara.

Ahmadi, Abudan Supriyono, Widodo, 2017, Psikologi Belajar, Jakarta: Rineka Cipta.

Anshari MH, 1996, Kamus Psikologi, Surabaya: Usaha Nasional.

Anwar, D, 2001, Kamus Lengkap Bahasa Indonesia, Surabaya: KaryaAbditama.

Arifin, 1996, Filsafat Pendidikan Islam, Jakarta: Bumi Aksara.

Dahlan, Soranji Dahlan dan Asy'ari, 2009, Pendidikan Kewarganegaraan untuk SMP Kelas VII, Jakarta: Penerbit Erlangga.

Danim, Sdan Khairil, 2011, Psikologi Pendidikan (dalam Perspektif Baru), Bandung: Alfabeta.

Delors, 1996, Education: The Necessary Utopia, Pengantar di dalam 'Treasure Within' Report the International Commission on Education for the Twenty-firs Century", Paris: UNESCO Publishing.

Depdiknas, 2003, Pedoman Penciptaan Suasana Sekolah Yang Kondusif Dalam Rangka Pembudayaan Budi Pekerti Lubur Bagi Warga Sekolah Buku II, Jakarta: Direktorat Jenderal Pendidikan Dasar dan Menengah.

Djauhari, 1997, Pendidikan Islam dari Masa ke Masa, tt: Mairifah, 1997, Vol. 3

El-Ghaniy, A, 2009, Saat Anak Harus Dihukum, Yogyakarta: Power Books IHDINA.

Imron Ali, 2012, Manajemen Peserta Didik Berbasis Sekolah, Jakarta: BumiAksara.

Kartono, 1997, Patologi Sosial; Tiga Gangguan-Gangguan Kejiwaan, Jakarta: Raja Grafindo Persada.

Kompas, Edisi Jumat 2 Februari 2018. 
82 | BELAJEA : Jurnal Pendidikan Islam, Vol. 3, No. 1, 2018

Liang GieThe, 1992, Kamus Administrasi, Jakarta: BPA GAMA, Gunung Agung.

Moleong, Lexy J, 2007, Metodologi Penelitian Kualitatif, Bandung: Remaja Rosdakarya.

Nawawi, Hadari, 1992, Administrasi Pendidikan, Jakarta: Gunung Agung.

Ngalim Purwanto, M, 1995, Psikologi Pendidikan, Jakarta: PT Remaja Rosdakarya.

NgalimPurwanto, M, 2007, Imu Pendidikan Teoritis dan Praktik, Bandung: Remaja Rosdakarya.

Nizar, Samsul dan Hasibuan, 2011, Hadis Tarbawi, Jakarta: Kalam Mulia.

Noah, W, 1989, Dictionary of English Language, New York: Portland.

Ormrod JE, 2009, Psikologi Pendidikan: Membantu Siswa Tumbuh dan Berkembang, Jakarta: Penerbit Erlangga.

Priyanto, 1977, Pelayanan Bimbingan di Sekolah, Jakarta: Ghalia Indonesia.

Raka, Gede, dkk, 2011, Pendidikan Karakter di Sekolab: dari Gagasan ke Tindakan, Jakarta: PT Gramedia.

Rifa'i, Adan Catharina, TA, 2011, Psikologi Pendidikan, Semarang: UNNES Press.

Sadulloh, Usman, 2011, Pedagogik (Ilmu Mendidik), Bandung: Alfabeta.

Sardiman, 2011, Interaksi dan Motivasi Belajar, Jakarta: Rajawali Pers.

Shoimin, A, 2014, 68 Model Pembelejaran Inovatif dalam Kurikulum 2013, Yogyakarta: Ar-Ruzz Media. 